\title{
PENGEMBANGAN MODUL AJAR TEKNOLOGI INFORMASI DAN KOMUNIKASI (TIK) POKOK BAHASAN PROGRAM PENGOLAH ANGKA BERORIENTASI LEARNING CYCLE UNTUK SISWA KELAS VIII DI SMP NEGERI 1 KUBUTAMBAHAN
}

\author{
I Gede Krisna Mahendra ${ }^{1}$, Dessy Seri Wahyuni ${ }^{2}$, I Gede Ratnaya ${ }^{3}$ \\ ${ }^{1}$ Mahasiswa Pendidikan Teknik Informatika Universitas Pendidikan Ganesha \\ Email: krisnak8@yahoo.com \\ ${ }^{2}$ Staf Pengajar Pendidikan Teknik Informatika Universitas Pendidikan Ganesha \\ Email: dessy@gmail.com \\ ${ }^{3}$ Staf Pengajar Pendidikan Teknik Informatika Universitas Pendidikan Ganesha
}

\begin{abstract}
ABSTRAK
Penelitian ini bertujuan untuk : (1) Merancang dan mengimplementasikan pengembangan modul ajar TIK (Teknologi Informasi dan Komunikasi) berorientasi Learning Cycle untuk siswa kelas VIII di SMP N 1 Kubutambahan (2) Untuk mengetahui respon siswa kelas VIII di SMP N 1 Kubutambahan terhadap modul ajar TIK (Teknologi Informasi dan Komunikasi) yang dikembangkan berorientasi Learning Cycle

Subyek penelitian adalah ahli isi pembelajaran dan siswa kelas VIII di SMP Negeri 1 Kubutambahan tahun pelajaran 2010/2011. Jenis penelitian yang dilakukan adalah penelitian pengembangan yang memakai Model Dick and Carey (1990). Keluaran utama yang dihasilkan berupa modul ajar TIK pokok bahasan program pengolah angka berorientasi learning cycle. Data yang dikumpulkan berupa data karakteristik peserta didik, model pembelajaran dan sumber belajar, penilaian serta revisi dari ahli isi pembelajaran, dan terakhir respon siswa terhadap pengembangan modul ajar TIK berorientasi learning cycle yaitu dengan menggunakan angket. Data yang telah dikumpulkan dianalisis dengan teknik analisis deskriptif, yaitu berupa analisis pembelajaran dan sumber belajar, analisis karakteristik siswa, analisis kevalidan modul ajar dan terakhir analisis data respon siswa.

Hasil penelitian ini menunjukkan bahwa : telah tercipta sebuah modul ajar TIK pokok bahasan program pengolah angka berorientasi learning cycle dengan respon siswa tersebar pada kategori sangat positif $8 \%$, positif $12 \%$, cukup $60 \%$, negatif $12 \%$ dan sangat negatif $12 \%$. Rata-rata skor respon siswa yaitu 96.04, sehingga respon siswa terhadap pengembangan media ini dapat dikategorikan cukup.
\end{abstract}

Kata - kata kunci : Modul ajar, TIK (Teknologi Informasi dan Komunikasi), Model Dick and Carey dan Learning Cycle 
ISSN 2089-8673

Jurnal Nasional Pendidikan Teknik Informatika (JANAPATI)

Volume 1, Nomor 2, Juli 2012

\section{PENDAHULUAN}

\subsection{Latar Belakang}

Seorang guru dituntut untuk merancang proses pembelajaran dengan menghadirkan sumber belajar yang tepat agar proses pembelajaran dapat berlangsung secara efektif dan menyenangkan. Guru sebagai ujung tombak pendidikan diharapkan dapat memotivasi siswa untuk berperan aktif dalam proses pembelajaran serta mampu untuk belajar secara mandiri atau membelajarkan diri sendiri (self instructional) sehingga mencapai kompetensi minimal yang telah ditentukan dan menghadirkan pembaharuan dalam proses pembelajaran untuk peningkatan mutu pendidikan.

Mata pelajaran TIK memerlukan sumber dan bahan belajar yang tepat sehingga dapat membantu siswa belajar secara mandiri dan pembelajaran berlangsung lebih efektif. Berdasarkan observasi awal yang dilakukan peneliti di SMP Negeri 1 Kubutambahan, beberapa faktor yang menyebabkan belum terpenuhi kriteria ketuntasan minimal yang ditetapkan adalah sebagai berikut : kurang adanya sumber belajar yang sesuai untuk kondisi siswa, kondisi infrastruktur yang masih minim. Dari hasil wawancara dengan guru bidang studi TIK, kondisi proses pembelajaran TIK selama ini adalah sebagai berikut: sumber belajar siswa hanya berupa LKS dan belum menggunakan modul ajar yang mampu mengkotruksi atau membangun pemahaman dan pengetahuan siswa untuk belajar secara mandiri dan efektif sesuai dengan waktu yang disediakan.

Guru sebaiknya memberikan kesempatan kepada siswa untuk melakukan eksplorasi pengetahuan yang akan dipelajari dengan demikian siswa akan belajar mengkonstruksi pengetahuannya sendiri dan dengan kondisi belajar yang lebih melibatkan siswa dalam proses pembelajaran. Guru dapat memilih salah satu model pembelajaran yang berpusat pada peserta didik yaitu siklus belajar. Siklus belajar terdiri dari 3 tahapan yaitu: 1) Tahap eksplorasi, 2) tahap pengenalan konsep, dan 3) tahap aplikasi konsep (lawson, 1996). Selama tahap eksplorasi siswa melakukan penyelidikan terhadap fenomena baru yang menjadi pertanyaan dan untuk menemukan dari fenomena tersebut. Pada tahap pengenalan konsep, guru memperkenalkan konsep-konsep yang berhubungan dengan pola yang telah ditemukan pada eksplorasi, sedangkan pada tahap aplikasi konsep, siswa diberi kesempatan untuk menerapkan konsepsi barunya dalam situasi yang baru. Dengan menggunakan model pembelajaran learning cycle diharapkan nantinya siswa akan menjadi lebih aktif dan mandiri dalam mengikuti proses pembelajaran mata pelajaran TIK di kelas serta memudahkan mereka dalam memahami konsep mata pelajaran TIK agar mempermudah siswa untuk praktek. Terwujudnya situasi belajar yang aktif dan mandiri hendaknya dibantu dengan sumber belajar berorientasi model pembelajaran. Dari observasi awal didapatkan guru dan siswa di SMP Negeri 1 kubutambahan belum memiliki dan belum pernah menggunakan sumber belajar berupa modul ajar dengan berorientasikan learning cycle.

Berdasarkan hasil penelitian Siti Djumhurijah (2008) bahwa dengan penggunaan model pembelajaran Learning Cycle guru mampu meningkatkan ketuntasan belajar siswa dan antusias siswa dalam pembelajaran semakin aktif, kreatif dan inovatif. Sejalan dengan temuan itu Suhemi Sya'ban (2003) menemukan bahwa siklus belajar dapat meningkatkan kualitas pembelajaran. Berdasarkan latar belakang di atas penulis ingin mengembangkan modul ajar TIK pokok bahasan program pengolah angka berorientasi Learning Cycle untuk siswa Kelas VIII di SMP N 1 Kubutambahan.

\subsection{Rumusan Masalah}

Permasalahan yang akan dikaji dalam penelitian ini dapat dirumuskan sebagai berikut:

1. Bagaimanakah rancangan dan implementasi modul ajar TIK (Teknologi Informasi dan Komunikasi) pokok bahasan program pengolah angka yang dikembangkan berorientasi Learning Cycle untuk siswa Kelas VIII di SMP N 1 Kubutambahan?

2. Bagaimanakah respon siswa kelas VIII di SMP N 1 Kubutambahan terhadap modul ajar TIK (Teknologi Informasi dan Komunikasi) pokok bahasan program pengolah angka yang dikembangkan berorientasi Learning Cycle? 
ISSN 2089-8673

Jurnal Nasional Pendidikan Teknik Informatika (JANAPATI)

Volume 1, Nomor 2, Juli 2012

\subsection{TUJUAN}

Tujuan yang ingin dicapai dalam penelitian ini adalah sebagai berikut:

1. Merancang dan mengimplementasikan pengembangan modul ajar TIK (Teknologi Informasi dan Komunikasi) pokok bahasan program pengolah angka berorientasi Learning Cycle untuk siswa kelas VIII di SMP N 1 Kubutambahan.

2. Untuk mengetahui respon siswa kelas VIII di SMP N 1 Kubutambahan terhadap modul ajar TIK (Teknologi Informasi dan Konmunikasi) pokok bahasan program pengolah angka yang dikembangkan berorientasi Learning Cycle.

\subsection{MANFAAT}

Adapun manfaat yang ingin diperoleh dalam penelitian ini adalah sebagai berikut.

1. Manfaat Teoritis

Manfaat teoritis dari penelitian ini adalah dapat memberikan sumbangan pikiran yang positif guna pengembangan dan kemajuan kemampuan siswa dalam hal Teknologi Informasi dan Komunikasi

2. Manfaat Praktis

1) Bagi Siswa (subjek didik)

Siswa mengetahui dan mendapat pengalaman belajar dari sumber belajar lain, selain sumber belajar yang mereka gunakan sebelumnya.

2) Bagi Guru

Memberikan gambaran pemahaman yang lebih baik tentang langkah-langkah pengembangan modul ajar berorientasi learning cycle sebagai sumber ajar yang nanti dapat diharapkan membantu proses belajar mengajar di kelas.

3) Bagi Peneliti

Peneliti akan memperoleh pengalaman dalam penilitian khususnya yang berkaitan dengan penelitian pengembangan modul ajar TIK pokok bahasan program pengolah angka berorientasi learning cycle.

\section{KAJIAN PUSTAKA}

Teori dan model rancangan pembelajaran hendaknya memperlihatkan tiga komponen utama, yaitu (1) kondisi belajar, (2) metode pembelajaran, dan (3) hasil pembelajaran. Berdasarkan penjelasan tersebut, pengembangan modul harus mengikuti langkah-langkah yang sistematis. Langkah-langkah tersebut adalah

1. Analisis tujuan dan karakteristik isi bidang studi.

2. Analisis sumber belajar.

3. Analisis karakteristik pebelajar.

4. Menetapkan sasaran dan isi pembelajaran.

5. Menetapkan strategi pengorganisasian isi pembelajaran.

6. Menetapkan strategi penyampaian isi pembelajaran.

7. Menetapkan strategi pengelolaan pembelajaran.

8. Pengembangan prosedur pengukuran hasil pembelajaran.

Langkah-langkah (1), (2), (3), dan (4) merupakan langkah analisis kondisi pembelajaran, langkah-langkah (5), (6), dan (7) merupakan langkah pengembangan, dan langkah (8) merupakan langkah pengukuran hasil pembelajaran. Salah satu model pengembangan yang mengikuti langkah-langkah tersebut adalah model pengmbangan Dick and Carey.

Model pengembangan Dick and Carey terdiri dari lima tahap yaitu: 1) tahap penetapan materi pelajaran, 2) tahap analisis kebutuhan, 3) tahap pengembangan modul, 4) tahap penyusunan modul, 5) tahap review/uji coba. Bagan alir tahapan pengembangan ditunjukan pada gambar 2, berikut bagan dari model pengembangan Dick and Carey secara umum. 
ISSN 2089-8673

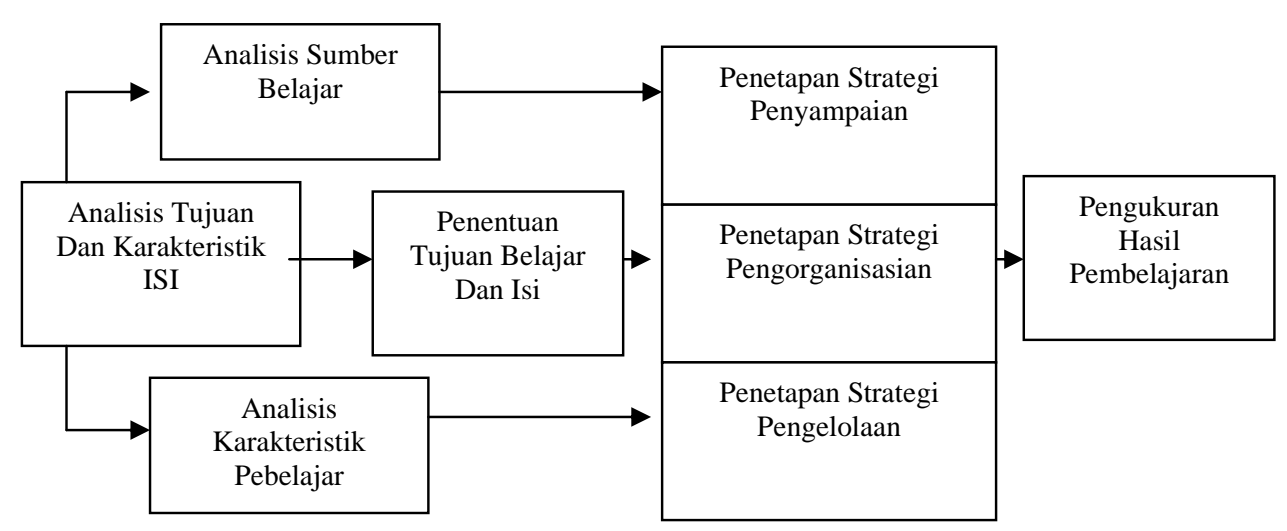

Gambar 2.1 Desain Pengembangan Pembelajaran (Santyasa, 2009)

Penelitian ini merupakan jenis Penelitian Pengembangan atau dalam bahasa Inggrisnya Research and Development adalah metode penelitian yang digunakan untuk menghasilkan produk tertentu, dan menguji keefektifan produk tersebut. Pengembangan yang digunakan untuk mengembangkan modul ajar teknologi informasi dan komunikasi (TIK) pokok bahasan program pengolah angka berorientasi learning cycle untuk siswa kelas VIII di SMP negeri 1 kubutambahan. tahapan-tahapan yang dilakukan dalam pengembangan modul ajar ditunjukkan pada gambar 1.

\section{METODE PENELITIAN}

\subsection{Jenis Penelitian}

Penelitian ini merupakan jenis Penelitian Pengembangan atau dalam bahasa Inggrisnya Research and Development adalah metode penelitian yang digunakan untuk menghasilkan produk tertentu, dan menguji keefektifan produk tersebut.

\subsection{Populasi Penelitian}

Populasi adalah wilayah generalisasi yang terdiri atas: obyek/subyek yang mempunyai kualitas dan karakteristik tertentu yang ditetapkan oleh peneliti untuk dipelajari dan kemudian ditarik kesimpulannya (Sugiyono, 2010). Subjek penelitian adalah berupa benda, hal atau tempat variabel melekat dan yang dipermasalahkan (Arikunto, 2005). Dengan demikian subjek dalam penelitian ini adalah siswa dan ahli isi pembelajaran. Sedangkan objek dalam penelitian ini adalah modul ajar TIK pokok bahasan program pengolah angka berorientasi learning cycle dan respon siswa kelas VIII di SMP Negeri 1 Kubutambahan terhadap pengembangan modul ajar TIK pokok bahasan program pengolah angka berorientasi learning cycle.

\subsection{Model Pengembangan}

Penelitian ini merupakan penelitian pengembangan modul ajar TIK pokok bahasan program pengolah angka berorientasi Learning Cycle untuk kelas VIII di SMP Negeri 1 Kubutambahan. Namun pada penelitian ini, penulis tidak sampai pada pengukuran hasil pembelajaran, hanya pada tahap pengembangan dan menganalisis respon siswa terhadap modul ajar yang dikembangkan. Model pengembangan yang digunakan mengacu pada model pengembangan Model Dick and Carey. Tahapan pengembangan terdiri dari lima yaitu:

1. Tahap Pertama

Pada tahap ini menentukan mata pelajaran yang menjadi objek pengembangan. Mata pelajaran yang akan dijadikan objek pengembangan modul oleh penulis yaitu mata pelajaran TIK. 
ISSN 2089-8673

Jurnal Nasional Pendidikan Teknik Informatika (JANAPATI)

Volume 1, Nomor 2, Juli 2012

2. Tahap Kedua

Menganalisis segala sesuatu yang diperlukkan dalam pengembangan modul ajar seperti :

a. Analisis Pembelajaran dan Sumber belajar

Analisis Pembelajaran dan sumber belajar dilakukan untuk mengetahui buku - buku atau tutorial yang digunakan oleh guru, langkah-langkah atau cara guru dalam menyampaikan materi sehingga siswa menjadi tertarik untuk belajar.

3. Tahap Ketiga

Tahap proses pengembangan draft. Pada tahap ini melakukan analisis terhadap pembelajaran dan langkah pengembangan.

(1) Mengidentifikasikan Kurikulum

Kurikulum yang digunakan di SMP N 1 Kubutambahan untuk kelas VIII adalah KTSP (Kurikulum Tingkat Satuan Pendidikan).

(2) Menganalisis Kompetensi dan Indikator Hasil Belajar

Mengidentifikasi dan menganilisis kompetensi dan indikator yang harus dikuasai siswa SMP berdasarkan kurikulum yang digunakan.

(3) Mengidentifikasi Tingkah Laku dan Karakteristik Masukan

Analisis karakteristik ini diperoleh melalui angket karakteristik siswa. Analisis ini bertujuan mengetahui karakteristik siswa sebagai acuan dalam pengembangan modul ajar

(4) Merumuskan Kompetensi Dasar dan Indikator Hasil Belajar

Merumuskan hasil belajar yang ingin dicapai dengan mengacu pada standar kompetensi yang dibuat. Karena keterbatasan waktu jadi penulis hanya menetapkan satu standar kompetensi yaitu "Menggunakan Perangkat Lunak Pengolah Angka untuk Menyajikan Informasi".

(5) Mengembangkan Strategi Isi Pembelajaran

Strategi isi pembelajaran adalah menjelaskan komponen-kompenen umum dari suatu perangkat bahan pembelajaran dan prosedur-prosedur yang akan digunakan bersama-sama bahan-bahan tersebut untuk mencapai hasil belajar dari siswa (Dick \& Carey, 1990).

Strategi penyampaian isi modul direncanakan menggunakan strategi pembelajaran Learning Cycle dengan memilih tipe Empiris Induktif karena menurut Lawson dan Renner (dalam Sudiatmaka, 1997), tipe Empiris Induktif cocok diterapkan untuk anak SMP

(6) Mengembangkan Instrumen Evaluasi Uji Ahli dan Angket Respon Siswa

Pada tahap ini penulis merancang instrumen evaluasi uji ahli, uji coba perorangan, uji coba kelompok kecil dan angket respon siswa untuk dipergunakan pada tahap kelima yaitu tahap review atau uji coba

4. Tahap Keempat

Tahap Penyusunan draft meliputi tahap penyusunan modul ajar berupa Kata Pengantar, Kompetensi Dasar dan Indikator Hasil Belajar, Kegiatan Belajar dan Daftar Pustaka. Pada kegiatan belajar yaitu menentukan isi pembelajaran dengan penjabaran meliputi fase eksplorasi, pengenalan konsep dan aplikasi konsep, rangkuman, tes, kunci jawaban dan umpan balik.

Penjabaran modul ajar TIK program pengolah angka berorientasi Learning Cycle disingkat LC direncanakan terdiri dari : materi untuk kegiatan eksplorasi, materi pengenalan konsep TIK, dan pertanyaan serta tugas untuk aplikasi konsep yang telah dimiliki siswa. Tipe LC empirif-induktif dipilih untuk diterapkan dalam modul. Melalui modul ini nantinya siswa akan belajar berdasarkan tiga tahap sesuai dengan LC, yaitu

a) Materi Tahap Eksplorasi

Pada tahap ini materi modul bertujuan untuk mendapatkan perhatian siswa, mendorong kemampuan berpikir, membantu mereka mengakses pengetahuan awal yang telah dimilikinya. Timbulnya rasa ingin tahu siswa tentang tema atau topik yang akan dipelajari dengan memberikan pertanyaan-pertanyaan kepada siswa tentang fakta/fenomena yang berhubungan dengan materi yang akan dipelajari. 
ISSN 2089-8673

Jurnal Nasional Pendidikan Teknik Informatika (JANAPATI)

Volume 1, Nomor 2, Juli 2012

b) Materi Tahap Pengenalan Konsep

Pada tahap ini materi modul akan menguraikan atau memaparkan pengenalan materi dan pengembangan konsep TIK sesuai standar kompetensi serta indikator yang harus dimiliki dan dikuasai siswa.

c) Materi Tahap Aplikasi Konsep

Pada tahap ini didalam modul ajar akan terdapat beberapa latihan-latihan praktek dan soal-soal penerapan dari tahap pengenalan konsep yang siswa pelajari pada tahap sebelumnya.

\section{Tahap Kelima}

Tinjauan ahli dan uji coba terhadap produk yang dikembangkan. Pada tahapan ini modul ajar akan mengalami perubahan-perubahan dari penyusunan draft sebelumnya. Perbaikan diberikan oleh para ahli yaitu dari ahli isi pembelajaran. Setelah itu dilanjutkan uji perorangan siswa dan kelompok kecil siswa di SMp Negeri 1 Kubutambahan.

\section{HASIL DAN PEMBAHASAN}

Berdasarkan materi pokok mata pelajaran TIK yang digunakan sebagai acuan dalam penyusunan modul ini, serta berorientasi pada model pembelajaran learning cycle maka modul ini disusun dan dikembangkan menjadi empat bab pada tiap bab terdapat 3 tahapan model pembelajaran learning cycle yaitu: tahap 1 Eksplorasi, tahap 2 pengenalan konsep, tahap 3 aplikasi konsep. Adapun struktur modul ajar TIK pokok bahasan program pengolah angka berorientasi learning cycle adalah sebagai berikut:

I. Cover Modul Ajar

II. Kata Pengantar

III. Daftar Isi

IV. Daftar Gambar

V. Daftar Tabel

VI. Sampul BAB I : Menu dan Ikon Perangkat Lunak Pengolah Angka

- Tahap 1 Eksplorasi

- Tahap 2 Pengenalan Konsep

- Tahap 3 Aplikasi Konsep

- Rangkuman

- Pengujian diri

- Kunci Jawaban dan Umpan Balik

VII. BAB II : Penggunaan Menu dan Ikon Perangkat Lunak Pengolah Angka

- Tahap 1 Eksplorasi

- Tahap 2 Pengenalan Konsep

- Tahap 3 Aplikasi Konsep

- Rangkuman

- Pengujian diri

- Kunci Jawaban dan Umpan Balik

VIII. BAB III : Pembuatan Dokumen Pengolah Angka Program Microsoft Excel

- Tahap 1 Eksplorasi

- Tahap 2 Pengenalan Konsep

- Tahap 3 Aplikasi Konsep

- Rangkuman

- Pengujian diri

- Kunci Jawaban dan Umpan Balik

IX. BAB IV : Rumus dan Fungsi untuk Manipulasi Data

- Tahap 1 Eksplorasi

- Tahap 2 Pengenalan Konsep

- Tahap 3 Aplikasi Konsep

- Rangkuman

- Pengujian diri

- Kunci Jawaban dan Umpan Balik

X. Rangkuman Modul Ajar

XI. Soal-soal 
ISSN 2089-8673

Jurnal Nasional Pendidikan Teknik Informatika (JANAPATI)

Volume 1, Nomor 2, Juli 2012

\section{Daftar Pustaka}

Respon siswa terhadap pengembangan modul ajar TIK pokok bahasan program pengolah angka berorientasi learning cycle dikumpulkan dengan menggunakan angket respon siswa. Skor tiap respon siswa dapat dilihat pada tabel 1

Tabel 1Total Skor Respon Siswa Uji Coba Lapangan

\begin{tabular}{|r|r|l|l|l|l|r|}
\hline $\begin{array}{l}\text { Responden } \\
\text { Ke- }\end{array}$ & $\begin{array}{l}\text { Total } \\
\text { Skor }\end{array}$ & \multicolumn{1}{l|l}{$\begin{array}{l}\text { Responden } \\
\text { Ke- }\end{array}$} & $\begin{array}{l}\text { Total } \\
\text { Skor }\end{array}$ & $\begin{array}{l}\text { Responden } \\
\text { Ke- }\end{array}$ & $\begin{array}{l}\text { Total } \\
\text { Skor }\end{array}$ \\
\hline 1 & 99 & 11 & 92 & 21 & 88 \\
\hline 2 & 100 & 12 & 97 & 22 & 104 \\
\hline 3 & 102 & 13 & 95 & 23 & 96 \\
\hline 4 & 72 & 14 & 95 & 24 & 98 \\
\hline 5 & 97 & 15 & 118 & 25 & 95 \\
\hline 6 & 99 & 16 & 112 & & \\
\hline 7 & 101 & 17 & 108 & & \\
\hline 8 & 93 & 18 & 91 & & \\
\hline 9 & 93 & 19 & 70 & & \\
\hline 10 & 98 & 20 & 88 & & \\
\hline
\end{tabular}

Dari total skor respon siswa pada tabel 1 didapatkan nilai rata-rata (M) dan standar deviasi (SD) sebagai berikut.

$M=96,04$

$\mathrm{SD}=9,99$

Sehingga dari nilai rata-rata dan standar deviasi di atas, dapat ditentukan konversi respon siswa yang disajikan pada tabel 2 berikut.

Tabel 2 Konversi Respon Siswa

\begin{tabular}{|c|c|c|c|c|}
\hline No & Kelas Interval & Frekuensi & Persentase & Kategori \\
\hline 1. & $111,024 \leq \mathrm{X}$ & 2 & $8 \%$ & Sangat Positif \\
\hline 2. & $101,03 \leq \mathrm{X}<111,024$ & 3 & $12 \%$ & Positif \\
\hline 3. & $91,045 \leq \mathrm{X}<101,03$ & 15 & $60 \%$ & Cukup \\
\hline 4. & $81,055 \leq \mathrm{X}<91,045$ & 3 & $12 \%$ & Negatif \\
\hline 5. & $\mathrm{X}<81,055$ & 2 & $8 \%$ & Sangat Negatif \\
\hline
\end{tabular}

Respon siswa kelas VIII di SMP Negeri 1 Kubutambahan pengembangan modul ajar TIK pokok bahasan program pengolah angka berorientasi Learning Cycle tersebar pada kategori sangat positif $8 \%$, positif $12 \%$, cukup $60 \%$, negatif $12 \%$ dan sangat negatif $8 \%$. Ratarata skor respon siswa yaitu 96.04, sehingga respon siswa terhadap pengembangan media ini dapat dikategorikan cukup.

Persentase respon siswa terhadap pengembangan modul ajar TIK pokok bahasan program pengolah angka berorientasi learning cycle dapat disajikan pada gambar 2 berikut. 
ISSN 2089-8673

Jurnal Nasional Pendidikan Teknik Informatika (JANAPATI)

Volume 1, Nomor 2, Juli 2012

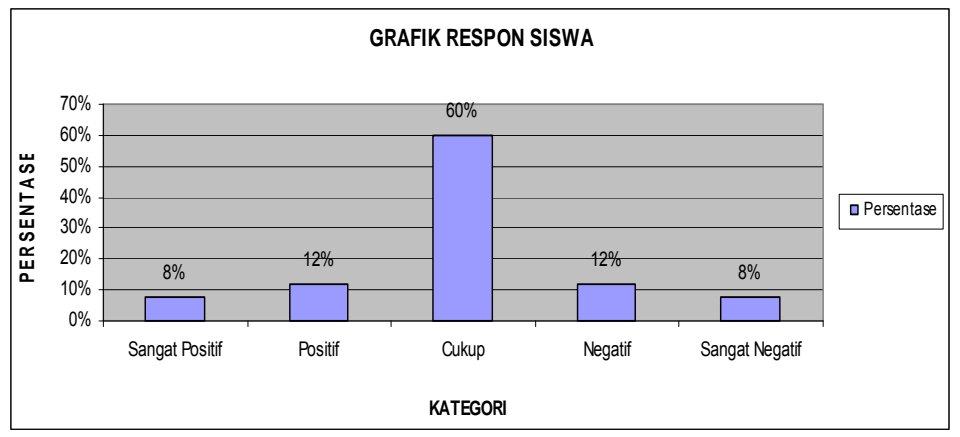

Gambar 2 Grafik Respon Siswa

Modul ajar TIK pokok bahasan program pengolah angka berorientasi learning cycle pada tiap bab materi dirancang dan diorientasikan dengan membagi menjadi tiga tahapan pembelajaran mengikuti model pembelajaran learning cycle disingkat LC, model pembelajaran LC berpusat pada pebelajar berdasarkan prinsip pembelajaran konstruktivis. Pada tiap bab materi disajikan dalam 3 tahapan yaitu tahap eksplorasi, pengenalan konsep dan aplikasi konsep. Implementasi modul didahuli dengan pembuatan draft modul. Modul ajar TIK memuat materi berdasarkan tujuan pembelajaran yang telah disusun dan dirumuskan dari standar kompetensi dan kompetensi dasar mata pelajaran TIK di SMP Negeri 1 Kubutambahan serta dari analisis karakteristik siswa yang dilakukan peneliti.

Berdasarkan analisis pembelajaran dan sumber belajar bahwa guru mata pelajaran TIK belum menggunakan modul ajar, sumber belajar yang digunakan guru sebatas buku paket dan LKS. Untuk Sumber belajar siswa menggunakan buku LKS itupun hanya beberapa orang anak saja. Selama ini guru mata pelajaraan TIK dalam pembelajaran belum pernah menerapkan model pembelajaran learning cycle. Oleh sebab itu perlu sekali dikembangkan modul ajar yang mampu menjadikan siswa untuk belajar secara mandiri dan tidak menjenuhkan bagi siswa serta guru mampu menghadirkan pembelajaran yang inovatif.

Dari analisis karakteristik siswa dapat diketahui bahwa mereka sangat tertarik dengan pembelajaran TIK, namun tingkat pemahaman akan materi mata pelajaran TIK masih dirasa kurang. Selama ini siswa belum pernah di ajak untuk melakukan eksplorasi. Mereka belum pernah atau belum memahami bagaimana mengeksplorasi untuk menggugah pengetahuan mereka dalam mengikuti pembelajaran dan pembentukan pemahaman konsep mata pelajaran TIK secara mandiri. Pada pembelajaran TIK siswa menginginkan lebih banyak praktek untuk itulah siswa memerlukkan sumber belajar yang membantu dan menuntun siswa untuk praktek.

Dari pengembangan modul ajar TIK pokok bahasan program pengolah angka berorientasi learning cycle, diharapkan dapat dimanfaatkan di sekolah dalam proses pembelajaran sehingga dapat membantu siswa dalam pembelajaran mata pelajaran TIK. Dengan penggunaan modul ajar ini siswa akan dapat melakukan eksplorasi sehingga dapat menggugah pengetahuan awal mereka dan timbulnya rasa ingin tahu akan materi pembelajaran TIK dengan timbulnya rasa ingin tahu dari siswa diharapkan muncul motivasi untuk mengikuti pembelajaran.

Sebelumnya modul ajar ini sudah mengalami tahap proses uji coba dan perbaikan. Perbaikan diberikan oleh para ahli yaitu dari ahli isi pembelajaran. Menurut uji ahli I modul ajar dilengkapi dengan rangkuman seluruh materi dan soal latihan pada akhir modul, ahli II modul ajar menyarankan mengubah ukuran font agar menambah gairah untuk membaca, dicantumkan tujuan pembelajaran serta pada aplikasi konsep mengadopsi kondisi real dan merupakan pemahaman yang dapat diaplikasikan. Atas penilaian ahli isi pembelajaran penulis merivisi modul ajar, hal ini dilakukan untuk menyempurnakan isi dari modul ajar, sehingga akan benar-benar bisa diterapkan di sekolah pada proses pembelajaran. Dengan adanya modul ajar ini nantinya dapat mengubah suasana pembelajaran lebih aktif dan siswa belajar secara mandiri. 
ISSN 2089-8673

Jurnal Nasional Pendidikan Teknik Informatika (JANAPATI)

Volume 1, Nomor 2, Juli 2012

Modul ajar ini sangat berperan penting dalam dalam proses pembelajaran. Dengan modul ajar ini siswa mengalami tahap proses pembentukan pengetahuan yang bertahap dari eksplorasi yaitu tahapan siswa untuk memancing timbulnya rasa ingin tahu tentang topik yang akan dipelajari dengan menjawab pertanyaan-pertanyaan yang ada pada tahap eksplorasi modul ajar. Setelah tahap eksplorasi dilanjutkan dengan tahapan pengenalan konsep. pada tahapan ini siswa diberikan pemahaman dan memperbaiki pengetahuan awal tahap eksplorasi yang siswa dapatkan dari pemaparan materi pada tahap pengenalan konsep modul ajar. Terakhir setelah tahap pengenalan konsep dilanjutkan ke tahap aplikasi konsep pada tahapan ini siswa mengaplikasikan pemahaman konsep mereka yang telah mereka dapatkan dari tahap pengenalan konsep melalui mengerjakan soal-soal latihan pada aplikasi konsep modul ajar.

Dari persentase respon siswa terhadap pengembangan modul ajar TIK pokok bahasan program pengolah angka berorientasi learning cycle untuk kelas VIII dapat dikategorikan ke dalam kategori cukup. Respon cukup tersebut menunjukkan bahwa siswa cukup senang dan siswa mampu belajar secara aktif dan mandiri.

\section{PENUTUP}

Berdasarkan hasil analisis data dan pembahasan pada penelitian ini, maka dapat diambil simpulan yaitu (1) Pengembangan Modul Ajar TIK Pokok Bahasan Program Pengolah Angka Berorientasi Learning Cycle untuk Siswa Kelas VIII di SMP Negeri 1 Kubutambahan dirancang dan diimplementasikan dengan menggunakan model pengembangan pembelajaran Dick and Carey, (2) Respon siswa terhadap pengembangan modul ajar ini berada pada kategori cukup sehingga modul ajar ini cukup layak diimplementasikan dalam pembelajaran. Tetapi masih kiranya perlu ada perbaikan agar nanti mendapat respon sangat positif dari siswa.

Berdasarkan pengamatan penulis, ada beberapa hal yang dapat dijadikan pertimbangan bagi pembaca antara lain yaitu: (1) Pengembangan modul ajar ini telah diujikan dan mendapatkan respon cukup, bagi peneliti selanjutnya dapat mengembangkan penelitian ini sampai pada tahap pengukuran hasil belajar serta dapat mengembangkannya menjadi penelitian eksperimen atau penelitian tindakan kelas, (2) bagi peneliti selanjutnya, dapat mengembangkan modul ajar selain untuk kelas VIII nanti juga mengembangkan modul ajar untuk kelas VII dan kelas IX, dan (3) bagi pengguna modul, dapat menggunakan modul ajar tersebut dengan sebaik mungkin dan diharapkan nanti pengguna memberikan revisi jika modul ajar ini perlu perbaikan sesuai dengan tuntutan tujuan pembelajaran jika ada perubahan. 


\section{DAFTAR PUSTAKA}

Arindawati, Anike Erlina dan Huda Hasbullah. 2004. Beberapa alternatif pembelajaran di sekolah dasar. Malang: Banyumedia publishing.

Budi Adnyani, Putu dan Citrawathi, Desak. 2007. Pengembangan Modul Biologi Berorientasi Siklus Belajar untuk Meningkatkan Penalaran dan Keterampilan Inkuiri Siswa SMA. Singaraja : Undiksha Singaraja.

Dick W \& I. Carey. 1990. The Systematic design of Intstruction, $3^{\text {rd }}$ ed. USA: Harper Cllins

Suheimi Syaba'an. 2003. Siklus belajar sebagai upaya meningkatkan kualitas pembelajaran dalam mempelajari hukum lavoiser siswa kelas 1 SMU Negeri Singaraja Tahun Ajaran 2002/2003. Tesis (tidak diterbitkan). PPS Universitas Negeri Malang.

Djumhurijah, Siti. 2008. "Penggunaan Model Pembelajaran Learning Cycle Untuk Meningkatkan Ketuntasan Belajar Siswa Pada Konsep Pemuaian Di Kelas VII di SMP Negeri 8 Bogor". $\quad$ http://www.docstoc.com/docs/36261501/djumhurijah-fisika-learning (diakses tanggal 20 Februari 2010). 